\title{
THE ELDERS: SENIORITY IN EARLIEST CHRISTIANITY ${ }^{1}$
}

\section{R. Alastair Campbell}

\section{Introduction}

The consensus view among Protestant scholars in this century has been that the elders who appear in the churches of the New Testament are the holders of a definite office of that name, which was derived from a similar office in the synagogue. The Jewish-Christian churches from very early on adopted a system of government by elders, along the lines of the synagogue, while the Pauline churches looked to the Spirit to direct the church through the operation of 'gifts' distributed to different members from time to time. In the latter, although in time certain administrative tasks necessitated the appointment of officers, these in no way compromised the freedom of the Spirit to direct the church through the ministry of apostles, prophets and teachers. By contrast, the elders, like their synagogue counterparts, were guardians of tradition, and represented the beginnings within the church of a pattern of government that would become legal and ecclesiastical. After Paul's death, the Pauline vision faded, and there took place an amalgamation of the two patterns, out of which Catholicism was born. Pauline overseers and deacons combined with Jewish-Christian elders to produce the threefold pattern of ministry, a nominal victory for the Pauline order of overseers and deacons, but in reality a retreat into religion that was scribal and clerical.

This consensus can be traced back to the views of Rudolf Sohm, according to which the Church knows nothing of Law, but operates entirely by charisma. However, Sohm, who did not himself distinguish between Pauline- and JewishChristianity in this way, saw the elders not as an office at all, but a rank. They were the church's most honourable members, and their charisma was 'the gift of Love'. Sohm's successors

${ }^{1} \mathrm{R}$. Alastair Campbell, The Elders: Seniority within earliest Christianity (unpublished PhD thesis, London University 1992), supervisor: Professor G.R. Stanton. 
moved the elders from the side of charisma to the side of Law. From being part of the Church's golden age of freedom, elders came to be seen as the first sure sign of its degeneration, incipient embodiments of the Law and of the churches' transformation into Christian synagogues.

\section{The Argument}

1. Although the earliest churches developed rapidly within a Graeco-Roman environment, their primary cultural heritage was, of course, Jewish. In Ancient Israel 'the elders' denoted a form of leadership that was collective and representative, with an authority derived from their seniority relative to those they represented, whether household, clan, tribe or nation. It was a term of honour for those whose power is based in relationships that already exist, rather than a precise office, entered through appointment, election or ordination.

Jewish writers of the Second Temple period (including New Testament writers when they refer to the Jewish leaders) display a notable lack of precision in the use of the term 'elders', usually linking it with other terms to reinforce the impression that the whole leadership was involved. Elders, we may say, are those who have $\pi \rho \varepsilon \sigma \beta \varepsilon \hat{\imath} o v$, rather than the holders of an office of eldership at either national or local level.

A particularly important question for the study of Christian origins is whether there was any office of elder either in the synagogue or in the community of Qumran. In both cases it is possible to say that the congregation gave precedence to persons of seniority, and used the term 'the elders' to refer to them, but there was not an office of elder as such to which a person might be appointed and with clearly defined functions.

2. In a brief review of constitutional developments in the Graeco-Roman world it is argued that there are important similarities as well as differences between that world and the Jewish. Both emerge from an archaic period whose government may be called aristocratic, in which the elders as local chieftains play a prominent part. In both worlds their peoples experienced, for much of the time, the autocratic rule of local kings and distant empires. Democracy, whether of the Athenian or modern variety, was not often, or for long, the experience of the peoples of the Graeco-Roman world. In most places at most times power lay with those born to wealthy

https://tyndalebulletin.org/ 
families, whose senior members were leaders in the state, city, or rural community. The leaders owed their position in society to the power of their family, and their position in the family to their relative seniority.

They were not often called oi $\pi \rho \varepsilon \sigma \beta v i \tau \varepsilon \rho o r$, which connoted rather a class of person to whom respect was instinctively felt to be due, not so much the leaders of the state or town, but one's own elders within family, clan or acquaintance. Although the Greeks held this respect in tension with a fear of the ageing process, it continued to be a cohesive force in first century life, as the writings of Plutarch show. Evidence from social anthropology leads us to expect that respect for older people would be maintained wherever the pattern of extended families was preserved, as it was in the Graeco-Roman world.

3. In the light of this, it is of the highest importance that the Pauline congregations came to birth within extended households. It is here argued that it would be a mistake to suppose that the reason Paul does not mention elders in his (generally acknowledged) letters is that he had some objection to them in principle. The contrary view rests on an incorrect view of the meaning and purpose of his charisma teaching. A better explanation lies ready to hand. The letters in question belong to the very early days of the Pauline congregations, when the church in a place may only have consisted of a single household congregation, or where, if there were several households relations between them were very informal and overshadowed by the Apostle's own pastoral oversight. Within his own household no kúpros would normally be known as 'the elder' (or even 'an elder'). 'The elders', on the other hand, would be a natural way to refer to the several kv́pior at the point where they started to meet together as the representative leadership of the church in a given place.

4. At the same time, if the churches Paul founded had elders in all but name, the 'churches of Christ in Judea' (Gal. 1:22) probably had 'overseers' from the start also, and for the same reason. The evidence of Acts suggests that the Jerusalem church met in homes, and if so, the well-to-do patron who placed his or her house at the disposal of the church will have exercised a leading role within it. It is this figure who stands between the dqbm of the Damascus Document and the 
غ̇ंírko $\pi 0 \imath$ of Philemon 1:1 to form a single and unbroken line of development grounded in the household matrix of the congregations.

References to the elders in Acts are not the proof we need that the Jewish-Christians organised themselves in a different way that betokens their imperfect emancipation from the synagogue, but are a collective term for the household leaders of the Jerusalem church considered as a representative group. If the Twelve, as the ruling group within the Jerusalem church, are sometimes to be included among the elders and are sometimes named separately alongside them, that is entirely in accordance with the way the term 'the elders' has been shown to behave in LXX Greek.

5. It follows that the Pastorals do not reflect the merging of two distinct patterns of organisation. Instead, the way in which they speak of elders in the plural, but of the overseer in the singular, makes sense, if they were written precisely to commend and legitimate the recognition of a single é $\pi$ i $\sigma \kappa o \pi \circ \varsigma$ from among those who, as غ̇ $\pi$ i $\sigma$ Ko $\pi 01$ in their own housechurches, have begun to be known as the elders of the church.

The Pastorals call for the appointment of elders in every city (Tit. 1:5). In the light of what we know of the household basis of the Pauline churches, the appointees can hardly be the household leaders themselves, since these will have been in position from the start. The verse refers rather to the appointment of monepiskopoi, leaders over the churches in the various cities, the words $\kappa \alpha \tau \dot{\alpha} \pi^{\prime} \lambda_{\imath} v v$ denoting the sphere or level of responsibility of the new overseers, in contrast to their more limited oversight hitherto.

6. This line of argument throws new light on the earliest documents outside the New Testament itself. The elevation of one of their number to be overseer necessarily involved some diminution of the prestige of the overseers not appointed, and cannot always have occurred without tension and resentment. Clement writes to champion the dispossessed elders against what he sees as the overweening claims of the monepiskopos, while Ignatius writes in the opposite sense. The church at Corinth is represented as having risen up against its elders, when in reality it has demoted most of the elders in favour of the monepiskopos. Ignatius flatters the elders while depriving them of any active role. 
Yet the elders did not just fade away. They were senior Christians, possessed of considerable powers of patronage in the church. Nor on the other hand did they immediately join the ranks of the clergy. Evidence of this is provided by the references to seniores laici in the North African churches of the fourth century.

\section{Conclusion}

The main proposition demonstrated in this thesis is that in the ancient world the elders are those who bear a title of honour, not of office, a title that is imprecise, collective and representative, and rooted in the ancient family or household. Sohm maintained long ago that the elders were 'not an office but a rank'. They were not appointed to be elders; rather, the bishop was appointed from among them. Yet Sohm tended to idealise them, speaking of people being elders in virtue of their length of faithful service, endowed with 'the gift of love'. Stressing the household context of the earliest churches shows how Sohm's view of the elders can be revived, but in a less idealised form. The elders are indeed the churches' 'honourables', but they are not honoured for their Christian character alone, but as leaders of families, hosts of the church, patrons of the weaker believers. They are not men of Law, nor yet men of Love; they are men of Leadership, that leadership that naturally falls to older men in the Ancient World.

This in turn raises the question: When the identity of the elders, and their relationship to charisma and Amt, is rightly understood, may we not think that twentieth century scholars have greatly exaggerated the diversity of the early churches' patterns of ministry? The elders have been one of the main supports for the idea of opposed forms of organisation in the first century church. They have been made to encapsulate a supposed difference of outlook between Paul and Jerusalem. When, however, we see that there is nothing distinctively Jewish about deferring to seniority, and moreover that there was not within Judaism a defined office of elder waiting to be either taken over or rejected by the churches, and when we see that nothing in Paul's charisma teaching implies a hostility to honour, order or office, does not the case for diversity in the church's ministry largely collapse? 